\title{
Motivations for sharing negative experiences through online review sites among different generations
}

\author{
Marina Laškarin Ažić ${ }^{{ }^{*}}$ and Petra Bačić ${ }^{2}$
}

\begin{abstract}
${ }^{1}$ Faculty of Tourism and Hospitality Management, University of Rijeka, Primorska 42, p.p. 97, 51410 Opatija, tel: 051-294-702, E-mail: marinal@fthm.hr

${ }^{2}$ Faculty of Tourism and Hospitality Management, University of Rijeka, Primorska 42, p.p. 97, 51410 Opatija, E-mail: petra.bacicı@live.com
\end{abstract}

* Corresponding author

\begin{abstract}
This research paper focuses primarily on the psychological aspects of dissatisfied tourists and their inner motivations to share negative online reviews (NORs). More precisely, the purpose of this research is to reveal how motivation to share NORs driven by dissatisfaction with the handling of complaints influences the perceived importance and usefulness of online review sites and the willingness to share information with others (altruism). The study also aims to understand differences among generations on both the model level and the path level.

To meet study objectives, this paper includes descriptive, bivariate and multivariate analyses on a sample of 419 respondents. Results show that motivation to share online reviews driven by dissatisfaction with complaint handling is an important predictor of altruism and utility. Moreover, utility has a positive influence on the perception of importance and altruism.
\end{abstract}

Keywords: Online review sites, negative reviews, dissatisfaction, service recovery

Citation: Ažić, M.L. and Bačić, P. (2020). Motivations for sharing negative experiences through online review sites among different generations. European Journal of Tourism Research 26, 2607 


\section{Introduction}

The dynamic business environment of today calls for information sources that can allow tourism and hospitality managers to stay close to their guests. Electronic word-of-mouth (e-WOM) represents one of the greatest sources for people who want to keep informed. The main roles behind the idea of electronic word-of-mouth go to users and reviewers, while managers are seen more as observers of their public reputation.

In the online environment, tourists have a unique opportunity to share and use user-generated content (UGC) about specific interests before, during and after their travel experience. Along with the growing trend of such content, the number of online review sites (ORSs) has also increased dramatically. Unlike blogs and wikis, ORSs aggregate short reviews from many travellers in a searchable database (Benckendorff, Xiang, \& Sheldon, 2019). Today ORSs are more than sites for informing potential guests; they can also be an important tool in building identity and brand awareness, and tourists, more than ever, enjoy sharing and reading reviews. From the perspective of the consumer, online reviews are often considered as useful, authentic, powerful ( $\mathrm{Li}$ and Hitt 2008), and more trustworthy than other information sources (Xiang \& Gretzel, 2010). According to Henning-Thurau et al. (2004), e-WOM is a positive or negative statement made by potential, actual or former customers about a product, service or company, which is made available to other people via the internet.

Compared with consumers who read reviews, tourists who share UGC are motivated by the purpose of sharing, regardless of whether they share positive or negative content. When it comes to dissatisfied tourists, existing academic literature points that dissatisfaction with services could be a strong predictor of behavioural response (Mohd Ishar \& Mohd Roslin 2016; Mattila \& Ro 2008). Singh \& Widing (1991) pointed out that the responses of management are key input for guests' perception of complaint handling. Hence, guest dissatisfaction with service can be viewed as a conflict, after which guests may be thrilled, satisfied, dissatisfied or disappointed, depending on how well management succeeded to meet the guest's expectations of handling complaint. When guest perception of service recovery is positive it can be a powerful reason for enhancing the relationship with the service provider. Known as the service recovery paradox, the model was introduced by McCollough and Bharadwaj (1992) and refers to situations in which a guest's post-failure satisfaction exceeds pre-failure satisfaction. However, when guests feel disappointed or dissatisfied with service recovery, they can be vengeful and perceive ORS benefits and importance differently than others do. According to Singh (1990), negative complaint responses can be categorized into three distinct dimensions: (1) voice responses-actions directed toward the seller, (2) private responses- exit and informal WOM, (3) third party responses - complaint action toward other institutions. Willingness to help others driven by dissatisfaction with service recovery in previous literature has been observed as altruistic punishment. As noted by Gonçalves Santos Silva et al. (2017) altruistic punishment is a possible consumer response to the unsatisfactory level of management reaction, whereby individuals see justice in sharing helpful information to others. Although those studies refer to guest behaviour in an offline environment, guests today in online environments have a similar choice of action when it comes to service recovery failure, which needs to be explored further.

Dissatisfaction with service recovery needs to be accompanied by motivational background in order to explain its causal relationship with negative word-of-mouth. Namely, according to Bach and Kim (2012), service failures and dissatisfaction cannot fully explain all the causes of complaining behaviours and negative WOM among consumers. 
Despite studies about negative reviews being very popular now in the field of tourism and hospitality business, there is little research focused on guests dissatisfied with service recovery. Thus, in order to give some new insights into this topic, this study aims to reveal: (1) the effects of dissatisfaction with complaint handling on perception of utility of online review sites, the perceived importance, and willingness to help others (altruism), and (2) whether generational groups moderate those relationships.

\section{Theoretical background and hypotheses}

\section{Negative WOM and altruism}

In previous research, intentions to share positive reviews about tourism experiences are often seen as manifested variables of endogenous loyalty intention constructs (Yi, Lin, Jin, \& Luo, 2017; FolgadoFernández, Hernández-Mogollón \& Duarte, 2017; Liu, et al. 2015). Unlike positive reviews, negative reviews are more often seen as exogenous variables in order to find out customers' perceptions or attitudes toward a business products or services (Meng, Dipietro, Gerdes, Kline \& Avant, 2018) or their influence on purchase behaviour (Kim, Wang, Maslowska, \& Malthouse, 2015), and probability to buy (Maslowska, Malthouse, \& Bernritter, 2016).

The existing literature classifies motivation for WOM in positive and negative way. According to Sundaram, Mitra \& Webster (1998) negative motivations incudes: (1) altruism (helping others without expecting a reward for it); (2) anxiety reduction (sharing negative experiences helps relieve frustration, anxiety and anger); (3) vengeance (revenge); and (4) advice seeking (to obtain more advice about a problem). In order to recognize differences, some previous studies have compared the effects of positive and negative reviews. For instance, Racherla and Friske (2012) report that negative reviews are perceived to be more useful than either extremely positive or moderate reviews, while Sweeney, Soutar \& Mazzarol (2014) research showed that positive reviews are more effective than negative ones. Ullrich and Brunner's (2015) report similar results, they indicate that a positive customer review counteracts a negative consumer review more effectively than a positive brand response.

According to Kim and Grunig (2011), dissatisfied guests actively search for solutions to their problems and after they realize that they cannot find a solution to their problems, their behaviour in handling information may change. In such a situation, not only will dissatisfied guests actively share their negative experiences but they will also search for more information about their problems or forward information of the service to potential guests. While their research focused on the communication action of consumers (search for solution to their problems) and how that manifested on dependent variables, including handling information, this research focuses on the communication action of service providers and the consumer's perception of that action. Among authors who recently researched such perception are Zhang, Omran \& Cobanoglu (2017). Although their research focused only on Y generation and positive outcome of service recovery, their findings showed that members of Y generation tend to engage in positive eWOM because of their active use of social media.

In order to find out factors that influence negative word of mouth there are few research. Recent study by Balaji, Khong, Chong (2016) indicate that contextual (feeling of injustice, firm attribution, firm image), individual (face-concern, and emotion regulation) and social networking factors (SNS use intensity and tie strength) influence customer intention to transmit negative reviews on social network sites. While an earlier study (Richins, 1983) pointed out three factors that positively influence negative word-of-mouth: (1) inappropriate mechanisms for complaint handling, (2) inadequate response to complaint, and (3) inefficient product/service repair. In order to find out how feelings and managerial 
response influence the sharing of negative thoughts, our research focused on motivational background, which includes dissatisfaction with managerial response regarding complaint handling.

The drive theory of social facilitation might explain why people are keen to share information with others. According to the theory, users are more willing to share information with others when they realize that they are not alone. Sommer, Wynes \& Brinkley (1993) found that social facilitation affects shopping behaviour, where shoppers accompanied by others spent more time in a store and purchased more as compared with lone shoppers, while Rafaeli \& Noy (2002) acknowledged that participants stayed longer in an auction site when they were exposed to a higher level of virtual presence. However, there are also other psychological motivators, which drive sharing negative experiences. For instance, helping to find what others might need or want, without expecting any reward for helping, represents a growing trend in today's online environment. Altruism refers to "preventing other potential guests from experiencing the same problems that they had" (Sundaram, Mitra, \& Webster, 1998). Enjoyment in helping others was found to be an important motive in sharing e-WOM. Munzel \& Kunz (2014) confirmed that altruism is the most important motivation for posting reviews after consumption, while Cheung \& Lee (2012) confirmed a significant relationship between enjoyment of helping and consumer WOM intention. Although there are no previous studies regarding the effect of dissatisfaction with complaint handling (as second-order dissatisfaction) on altruism, Sparks \& Browning (2010) revealed some important findings concerning first-order dissatisfaction. Namely, there are two reasons for sharing online complaints: recommendation to others to avoid an unhappy experience and revenge derived from the perceived injustice.

In this study, altruistic motivation is seen as an endogenous variable, depending on motivation for dissatisfaction with complaint handling, perception of utility and the importance of ORSs. We believe that dissatisfaction with complaint handling may be seen as a motivation to share negative online reviews and a predictor of motivation to share information with others. In other words, the more people are motivated to share NORs based on their dissatisfaction with the handling of their complaint, the more they will be eager to help others. Our first hypothesis states:

\section{$H_{1}$ : Motivation for dissatisfaction with problem handling is positively related to altruistic motivation.}

\section{Perception of utility and importance of online review sites}

Transparency afforded by the Internet allows firms to display their concerns not only for guests who are dissatisfied but also for other potential guests (Stevens, Spaid, Breazeale, \& Esmark-Jones, 2018). Namely, how hospitality enterprises manage guest relationships during the guests' stay is an interesting topic for those searching through tourist information on ORSs before selecting a destination or hospitality facility. More than a decade ago, Park \& Lee (2008) argued that with the growth of noncommercial communication (e-WOM) and its popularity among users, it is becoming harder for consumers to find what they want and to assess the usefulness of the information. Over the years, the Web has become "smarter" and all the data about consumers has been organized and transformed into meaning for computers. Today the Semantic Web is a concept representing a synergy of the programmes, enabling users to create data stores on the Web, build vocabularies, and write rules for handling data $\left(\mathrm{W}_{3} \mathrm{C}, 2 \mathrm{2015}\right)$. As the learning process improves, the Web will better "understand" users' needs for information, and thus provide information that is more useful. However, regarding perception of usefulness, people in different emotional states may have different views about information utility. Namely, emotions, relative to cognition, have higher potential to influence guests' decisions, considering that they stimulate the mind 3,00o faster than regular thought (Robinette \& Brand 2001). In line with this, Kim et al. (2012) found that functional and emotional values affect the perceived utility 
of UGC. Since dissatisfaction with complaint handling is a way of expressing negative thoughts or feelings, we hypothesized the following:

\section{$\mathrm{H}_{2}$ : Dissatisfaction with problem handling positively influences perception of ORS utility.}

As noted by Gonçalves Santos Silva et al. (2017), altruism is a way of consumer punishment, driven by dissatisfaction with service recovery, and perceived injustice of management response to their first dissatisfaction. Concerning online research, no studies have previously tested whether the perception of the utility of tourists who are dissatisfied with service recovery influence altruistic behavior online. However, previous studies have examined perceived usefulness through a polarity of product ratings. They revealed that negative reviews have more impact on consumer judgment than positive reviews (Basuroy, Chatterjee \& Ravid, 2003; Chevalier \& Mayzlin, 2006; Sen \& Lerman, 2007). Earlier studies on information systems adoption often used logic explained by the Technology Acceptance Model (TAM), which assumes that perceived usefulness and ease of use represent primary determinants of system use (Shang, Chen \& Shen, 2005). Based on the TAM, consumers' use of ORSs could be explained by the perceived usefulness and ease of use of ORSs. On the other hand, Trammell (2006) points out that an individual's selection of media depends on value they receive. If guests generally perceive ORSs as useful based on their perception of quality and value (Kim et al., 2012), is that the case for the dissatisfied guest, too? We seek to understand whether dissatisfaction influences the perception of utility and the importance (of ORSs) during the decision-making process (prior to tourist service booking). Although no previous research tested connection between utility and importance of ORS, we have assumed that if dissatisfied consumers find the information from ORS useful, their perception of importance will also increase. In addition, we have assumed that perceived importance ORS represent important precondition of willingness to help other. Based on previous arguments, hypotheses 3, 4 and 5 were formulated as follows:

\section{$\mathrm{H}_{3}:$ Perceived utility positively influences altruistic motivation}

$H_{4}$ : Perceived utility positively influences the perception of ORS importance

$\mathrm{H}_{5}$ : Perceived ORS importance positively influences altruistic motivation

Figure 1 presents the research hypotheses.

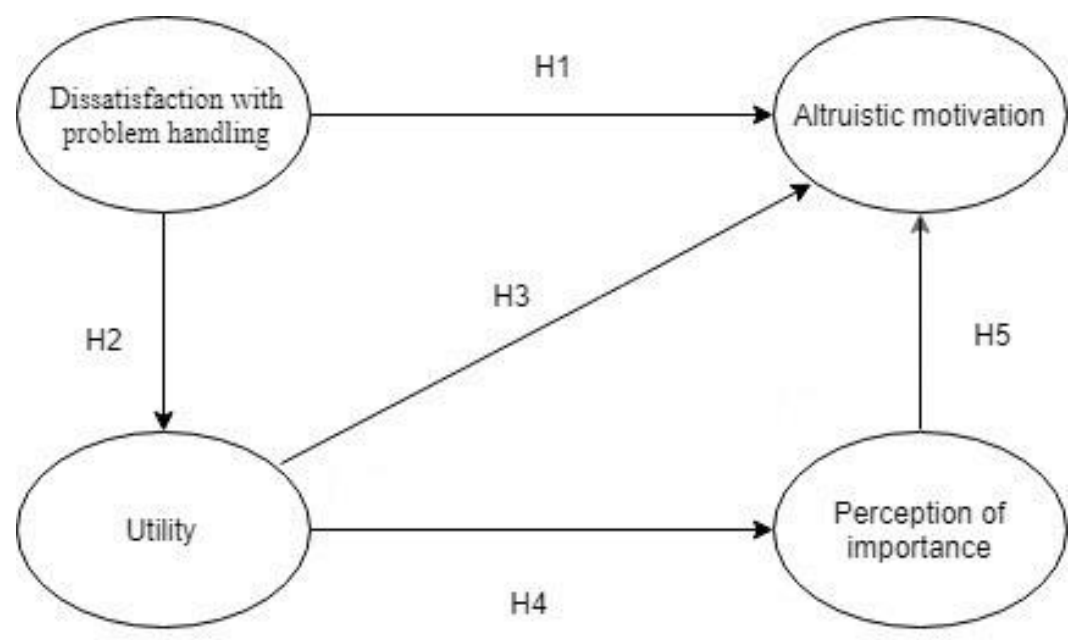

Figure 1. Proposed conceptual model and hypotheses 


\section{Methodology}

Data collection and sample

The advantages of online communities, such as convenience, low expenses and geographical diversity (Illum, Ivanov and Liang 2010), motivated us to use one of the most popular online communities for research purposes. According to WebFx, Facebook is the largest social network site and one of the top five review sites in the world. Hence, data for this study was collected through a Web-based survey, posted on Facebook over a 4-week period (January 2019), using non-probability convenience sampling method. In order to enhance the response rate of the online survey, we followed the general rules suggested by Illum, Ivanov and Liang (2010). The main condition for taking the survey was "recent experiences in traveling for pleasure". Since, the study was focused on dissatisfied tourists in a survey we used another screening question "Have you had a negative experience with handling complaint in previous 12 months". Of the 515 collected responses, 419 respondents had taken a pleasure vacation in the last 12 months and had a negative experience with handling complaint during their vacation. Based on the number of usable questionnaire, the response rate was $70.3 \%$.

In this study, a preliminary list of questions (measurement items) was selected based on previous literature review grouped in six sections. For instance, utility was measured using scale proposed by (Hennig-Thurau, Walsh \&Walsh 2003), while questions regarding altruistic motivation was based on a scale developed by (Henning-Thurau, Gwinner, Walsh, \& Gremler, 2004). To assess content validity of perception of importance and motivation for dissatisfaction with handling complaint, the questionnaire was examined and tested by academic and industry professionals. All measures were on seven-point Likert scales with anchors of "very likely (7) to very unlikely".

The last section included questions socio-demographic characteristic (nationality, sex, age -generations, education level). Having in mind that generation cohorts differ from age groups, experiences, critical life event and socio-economic trends this study use gen-classification suggested by Yang \& Lau (2015). Data Analysis was performed in two groups of steps. The first group involved descriptive and bivariate analysis to present the demographic profile and frequencies of use of online review sites. The second group comprised multivariate statistics. First, the independent sample t-test was used to compare whether differences exist between younger and older generations ( $\mathrm{Z}, \mathrm{Y}$ and $\mathrm{X}$, traditionalists) in the use of online review sites. Then, exploratory factor analysis (EFA), confirmatory factor analysis and, finally, structural equation modelling (SEM) were performed to test the hypothesized relationships.

\section{Results of descriptive and bivariate analysis}

The profile of 419 qualified respondents were presented in Table 1 . There are more female (83.8\%) than male respondents $(16.2 \%)$. The majority of respondents, aged 23 to 36 , belong to Generation Y (58.5\%), and there are no respondents in the over-74 group. It is also evident that there is an almost equal share of respondents who have finished high school (32.2\%), an undergraduate programme (27\%) and a graduate programme $(31.3 \%)$, while the minority of respondents are postgraduates.

Reading online reviews before traveling is becoming an essential part of tourist behaviour prior to confirmation of reservation. According to Gretzel and Yoo (2008), travel reviews play an important role in the planning process for those who actively read them. While their study refers to reviews as general information available online, this research focuses only on negative online reviews. Moreover, in this research we analyse the frequencies of reading and posting negative online reviews based on a 5-point Likert scale ( $1=$ never, 5 = always, if possible). 
Table 1. Demographic profile of respondents $n=419$

\begin{tabular}{lcc}
\hline Characteristic & Frequency $(\mathbf{n = 4 1 9 )}$ & Respondents (\%) \\
\hline Gender & & \\
$\quad$ Male & 68 & 16.2 \\
$\quad$ Female & 351 & 83.8 \\
Generation & 60 & \\
$\quad$ Generation $Z<22$ & 245 & 14.3 \\
Generation $Y$ 23-36 & 95 & 58.5 \\
Generation $X$ 37-52 & 19 & 22.7 \\
Baby boomers 53-73 & 0 & 4.5 \\
Traditionalists $>74$ & & 0 \\
Last finished education & 135 & 32.2 \\
High school & 113 & 27.0 \\
Undergraduate & 131 & 31.3 \\
Graduate & 40 & 9.5 \\
Postgraduate & &
\end{tabular}

Figure 2 clearly illustrates the inversely proportional relationship between the two variables. This is also supported by Pearson's correlation coefficient $(\mathrm{r}=-0.84)$. The correlation between the two variables indicates a very strong negative correlation. In other words, people who more frequently read negative online reviews tend to be less frequently post negative online reviews, and vice versa.

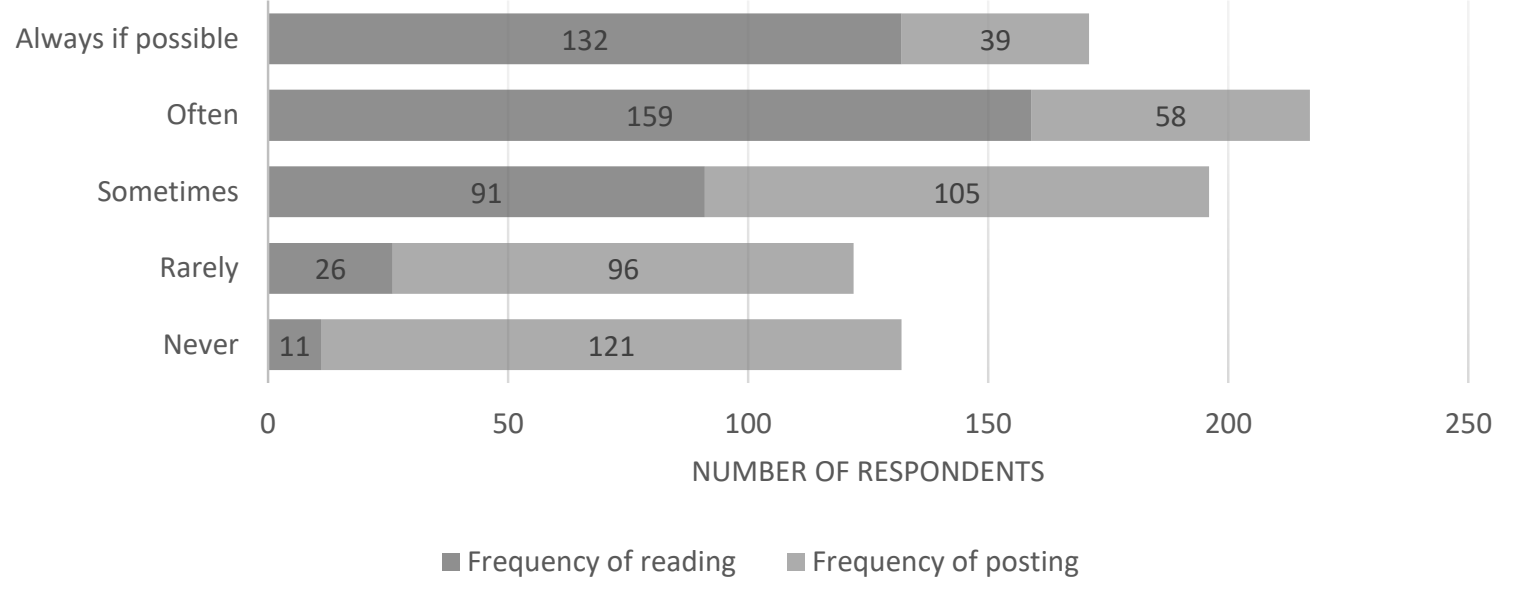

Figure 2. Frequencies of reading and posting negative online reviews

The parametric T-test was performed to test the difference between the arithmetic means of reading and posting negative online reviews between two group of generations ( $\mathrm{Y}, \mathrm{Z}$ and $\mathrm{X}$, Baby boomers) (Table 2). 
Table 2. T-test results

\begin{tabular}{lllll}
\hline Frequencies & $\begin{array}{l}\text { Generations } \\
\text { Y and Z } \\
\text { mean } \\
(\mathbf{n = 1 1 4})\end{array}$ & $\begin{array}{l}\text { Generation X } \\
\text { and Baby } \\
\text { boomers } \\
\text { mean }(\mathbf{n = 3 0 5})\end{array}$ & $\begin{array}{l}\text { t- } \\
\text { test }\end{array}$ & $\begin{array}{l}\text { Significance } \\
\text { (2-tailed) }\end{array}$ \\
\hline Reading negative online reviews & 3.86 & 3.98 & 1.090 & 0.276 \\
Posting negative online reviews & 2.48 & 2.62 & 1.017 & 0.310 \\
\hline
\end{tabular}

The t-test confirmed that there are no significant differences in reading negative reviews and posting negative reviews between older (X, Baby boomers) and younger ( $\mathrm{Y}, \mathrm{Z})$ generations. A slight difference, however, does exist between younger and older generations.

Results of multivariate analyses

As suggested by Steenkamp and Trijp (1991), exploratory factor analysis was performed first, followed by confirmatory factor analysis. The main purpose of EFA was to better understand factors, as the main dimensions of structural equation modelling. In order to compose variables in a set of fewer numbers of factors, the extraction method Maximum Likelihood with Promax with Kaiser Normalization rotation method was used. The value of the Kaiser-Meyer-Olkin (KMO) test was 0.82 , indicating a sufficient number of variables per construct. Bartlett's test was also significant $\left(\mathrm{x}^{2}=1580.378, \mathrm{df}=66, \mathrm{p}=0.000\right)$, suggesting a strong correlation between variables and their factors.

Table 3. Pattern Matrix

\begin{tabular}{|c|c|c|c|c|c|c|c|}
\hline & \multicolumn{4}{|l|}{ Factor } & $\begin{array}{l}\text { Cronbach's } \\
\text { alpha }\end{array}$ & \multirow[t]{2}{*}{ AVE \% } & \multirow[t]{2}{*}{ CR } \\
\hline & 1 & 2 & 3 & 4 & & & \\
\hline Motivation for dissatisfaction with handling & & & & & & & \\
\hline complaint & & & & & 0.855 & 61.2 & 0.85 \\
\hline Motive: Dissatisfaction with the manager's & & & & & & & \\
\hline $\begin{array}{l}\text { response to my problem } \\
\text { Motive: No reply to my direct complaint }\end{array}$ & 0.943 & & & & & & \\
\hline Motive: I disagree with the manager's & 0.001 & & & & & & \\
\hline response to previous online reviews & 0.630 & & & & & & \\
\hline Motive: Hurt feelings & 0.593 & & & & & & \\
\hline Utility (Hennig-Thurau, Walsh \&Walsh 2003) & & & & & 0.728 & 55.0 & 0.76 \\
\hline I use ORSs to reach the right decision & & 0.855 & & & & & \\
\hline I use ORSs to collect information & & 0.789 & & & & & \\
\hline I use ORSs to solve my problems & & 0.469 & & & & & \\
\hline Perception of importance before buying & & & & & 0.754 & 53.7 & 0.75 \\
\hline Importance of rating on TripAdvisor & & & 0.776 & & & & \\
\hline Importance of rating on social network & & & 0.758 & & & & \\
\hline Importance of rating on OTA & & & 0.575 & & & & \\
\hline Altruistic motivation (Henning-Thurau, & & & & & & & \\
\hline Gwinner, Walsh, \& Gremler, 2004) & & & & & 0.854 & $77 \cdot 3$ & 0.78 \\
\hline To inform others & & & & 0.908 & & & \\
\hline To advise others & & & & 0.678 & & & \\
\hline
\end{tabular}

Note: CR - composite reliability; AVE - average variance extracted 
Following the general rule of acceptable ratio of 5:1 or 10:1 (Hair, Black, Babin, \& Anderson, 2014), our model proposes 4 variables with 419 respondents, and the ratio is 105:1. The measurement model is reliable, as Cronbach's alpha values vary from 0.728 to 0.855 (Cronbach's alpha threshold=0.70). Communalities per variables are between 0.48 and 0.82 , indicating that variances of original values were well explained with extracted factors, while the cumulative percentage of variance is 61.293. In determining convergent validity, it is clear that factor loadings are higher than .40, what is considered acceptable. Namely, according to Hair et al., (2014) the minimum acceptable factor loading for a sample size of 350 or more is .30. Further, discriminant validity was tested by examining the factor correlation matrix (Table 4).

Table 4. Factor Correlation Matrix

\begin{tabular}{lllll}
\hline Factors & $\mathbf{1}$ & $\mathbf{2}$ & $\mathbf{3}$ & $\mathbf{4}$ \\
\hline $\begin{array}{l}\text { Motivation for dissatisfaction with } \\
\text { handling complaint }\left(\mathrm{F}_{1}\right)\end{array}$ & $\mathbf{0 . 7 8 2}$ & & & \\
Utility (F2) & & & & \\
Perception of importance before buying $\left(\mathrm{F}_{3}\right)$ & 0.303 & $\mathbf{0 . 7 4 2}$ & & \\
Altruistic motivation $\left(\mathrm{F}_{4}\right)$ & 0.570 & $\mathbf{0 . 7 3 3}$ & \\
\hline & 0.613 & 0.420 & 0.240 & $\mathbf{0 . 8 7 9}$ \\
\hline
\end{tabular}

Note: bolded diagonal values are square root of AVE

It can be seen that correlations between factors do not exceed 0.7, indicating that the model has no validity problems. After assurance in good explanation of representing factors, confirmatory factor analysis was used to test the proposed model fit (Table 5).

Table 5. Summary of model fit for confirmatory factor analysis

\begin{tabular}{lll}
\hline Indicators & Recommended values & Values \\
\hline Chi-Square $\mathrm{X}^{2}$ & & $100.604(\mathrm{p}=0.000)$ \\
Degrees of freedom $(\mathrm{df})$ & & 48 \\
CMIN/DF & $<3$ & 2.096 \\
Absolute Fit Measures & & \\
GFI & $>0.90$ & 0.962 \\
RMSEA & $<0.080$ & 0.051 \\
RMR & & 0.131 \\
SRMR & $<0.05$ & \\
NORMED chi-square & $2-5$ & \\
Incremental Fit Indices & & \\
NFI & $>0.90$ & 0.957 \\
CFI & $>0.90$ & 0.977 \\
Parsimony Fit Indices & & \\
AGFI & $>0.90$ & 0.938 \\
\hline
\end{tabular}

All squared correlations in the model (ranging from 0.058 to 0.458 ) are less than the AVE of the factor, showing that variables are strongly related to their own factor, and then to other factors (discriminant validity). The model also achieved construct validity (Table 3), considering that all standardized coefficients were significant, with acceptable AVE values exceeding the 0.50 threshold (Fornell \& Larcker, 1981). After assurance of good model fit for the measurement model, we conducted further analysis (Table 6) and checked the standardized coefficients (path coefficients) between exogenous and endogenous variables (Table 7 ). 
Table 6. Model fit -SEM

\begin{tabular}{lll}
\hline Indicators & Recommended values & Values \\
\hline Chi-Square & & 101.048 \\
Degrees of Freedom (Df) & & 49 \\
Probability Level & & 0.000 \\
Cmin/Df & $<3$ & 2.062 \\
Absolute Fit Measures & & \\
GFI & $>0.90$ & 0.962 \\
RMSEA & $<0.080$ & 0.050 \\
RMR & & 0.131 \\
SRMR & $<0.05$ & \\
NORMED chi-square & $2-5$ & \\
Incremental Fit Indices & & \\
NFI & $>0.90$ & 0.957 \\
CFI & $>0.90$ & 0.977 \\
Parsimony Fit Indices & & \\
AGFI & $>0.90$ & 0.939 \\
\hline
\end{tabular}

Table 7. Summary of structural model results - direct relationships

\begin{tabular}{|c|c|c|c|c|c|c|c|c|}
\hline & \multicolumn{3}{|c|}{ Structural relationship } & $\begin{array}{l}\text { Std. } \\
\text { coefficient }\end{array}$ & S.E. & C.R. & $\mathbf{p}$ & Result \\
\hline $\mathrm{H}_{1}$ & $\begin{array}{l}\text { Dissatisfaction } \\
\text { with problem } \\
\text { handling } \\
\text { Dissatisfaction } \\
\text { with problem }\end{array}$ & $\rightarrow$ & Altruism & 0.609 & 0.070 & 10.540 & $* * *$ & Supported \\
\hline $\mathrm{H}_{2}$ & handling & $\rightarrow$ & Utility & 0.307 & 0.051 & 4.990 & $* * *$ & Supported \\
\hline $\mathrm{H}_{3}$ & Utility & $\rightarrow$ & Altruism & 0.207 & 0.096 & 3.159 & 0.002 & Supported \\
\hline $\mathrm{H}_{4}$ & $\begin{array}{l}\text { Utility } \\
\text { Perception of } \\
\text { importance }\end{array}$ & $\rightarrow$ & $\begin{array}{l}\text { Perception of } \\
\text { importance }\end{array}$ & 0.595 & 0.06 & 7.872 & 0.070 & Supported \\
\hline
\end{tabular}

*** The probability of getting a critical ratio as large as 4.99 in absolute value is less than 0.001

As can be seen in Table 7 , dissatisfaction with problem handling is an important predictor of utility before buying $(\beta=0.307, \mathrm{p}<0.005)$ and altruism $(\beta=0.609, \mathrm{p}<0.005)$. The results show a strong relation between utility and perception of importance $(\beta=0.595, p<0.005)$, and utility and altruism $(\beta=0.207$, $\mathrm{p}<0.005)$. In addition to hypotheses testing, SEM results indicate an insignificant relationship between perception of importance and altruism $\left(\beta=0.024\right.$, p>0.005). To summarize, $\mathrm{H}_{1}, \mathrm{H}_{2}, \mathrm{H}_{3}$ and $\mathrm{H}_{4}$ were supported, while $\mathrm{H}_{5}$ was rejected.

Considering that the model contains a positive significant relationship between the exogenous variable (Dissatisfaction with problem handling) and the mediator (utility) and that the mediator is a significant predictor of the endogenous variable (Altruism), the model fulfilled the requirements for testing mediation effects (Sobel, 1982). To analyse the mediating effects of dissatisfaction with problem handling between utility and altruistic motivation, the sample number was set at 2000 and a $95 \%$ 
confidence interval was obtained through the non-parametric percentile bootstrap method (Jiang et al., 2018).

Table 8. Bootstrap results for indirect effects

\begin{tabular}{lllll}
\hline Structural relationship & Direct effect & Indirect effect & Total effect & Mediation \\
\hline $\begin{array}{l}\text { Dissatisfaction with complaint } \\
\text { handling -> Utility -> }\end{array}$ & & & & \\
Perception of importance & & & & \\
& $-0.037(0,567)$ & $.189(0.001)$ & $0.152(0,014)$ & Full mediation \\
$\begin{array}{l}\text { Utility -> Perceived } \\
\text { importance ->Altruism }\end{array}$ & $.207(0.002)$ & $.014(0.686)$ & $0.221(0.001)$ & No mediation \\
\hline
\end{tabular}

This table reports the lower bound and upper bound of $95 \%$ confidence interval of the indirect effects, $\beta=$ Standardized effects, $p$-values are shown within parentheses

Table 8 reports full mediation for the relationship between dissatisfaction with handling complaint $\rightarrow$ and Perception of importance. As suggested by Gaskin and Lyytinen (2011), p-value is $<0.05$ for the indirect effect and $>0.05$ for the direct effect. The results imply that utility played a key mediation role between the motivation: dissatisfaction with complaint handling and perception of importance. However, mediation of perceived importance was not confirmed for the relationship between utility and altruism.

In order to test differences between older and younger generations, multi group differences were tested based on chi-square difference using AMOS. Three groups of generations $(\mathrm{Z}, \mathrm{Y}, \mathrm{X})$ were included in the analysis while the Baby boomers group was excluded because of its small number (less than 20). Results show that groups do not differ at the model level (results for chi-square difference $=\mathbf{2 2 . 5 1}, \mathrm{df}=\mathbf{2 4}$, $\mathrm{p}$ value $>0.05$ ). Multi-group moderation was also tested for each path, and results shows that there is no difference between generations for each relationship in the model. Chi-square of each path is less than the chi square threshold (202.92 with 90\% confidence).

\section{Discussion of the results and managerial implications}

The purpose of this study was to understand the perceived importance of online review sites, the willingness to help others, and the interest in using online review sites of tourists who are motivated to share an online review about their dissatisfaction with complaint handling. The results revealed some interesting findings. First, dissatisfaction with complaint handling was found to be an important predictor of perceived utility of ORSs. In other words, people who were not satisfied with a manager's response (service recovery) perceived online review sites useful as a way to share NORs. This finding is consistent with a previous study by Maxham III (2001), who confirmed that consumer perception of recovery (satisfaction) has a significant influence on WOM. Because dissatisfaction seems to be a strong predictor of using online review sites, managers should be more mindful of their strategies for handling complaints. Those strategies should take into consideration the category of the problem (e.g. financial loss, hurt feelings, bad weather, etc.), the type of guest, and all situational factors that might influence perceived fairness during service recovery. During service recovery, guests are particularly sensitive as to how employees deal with them, thus, it is important that the service recovery process provides understanding, empathy and gratitude (Laškarin Ažić, 2018).

Second, the perceived utility of ORs is important precondition of perception of ORS importance (prior to the booking of hospitality services). This could be explained by the fact that dissatisfied tourists, who 
use ORSs to share negative reviews, perceive ORSs as being important prior to making a reservation. Dissatisfied consumers are extremely demanding, who appreciate a careful personalized response based on well-established service recovery steps (Gonçalves Santos Silva, et al. 2017). Thus, managers must be very careful in choosing a strategy for online responses (empowering community manages; which ORSs are they going to follow; are they are going to answer positive reviews, negative reviews or both, etc.). Third, this paper confirms that tourists who were not satisfied with service recovery are tourists who are eager to help others. Previous research has confirmed that expectations from online reviews can be twofold: the first category includes expectations of recognition, esteem, and enjoyment in online activities (Baym, 2010) while the second type of expectations is directed toward social recognition altruism. Since expectations from online reviews represent the starting point for developing motivational background, this research acknowledges altruism as a fundamental motivation which is significantly influenced by dissatisfaction with complaint handling. Fourth, unexpectedly results showed that the perception of importance ORSs was not significant antecedent of altruism. This nonsignificant result also offers some theoretical value by suggesting future researchers to incorporate these factors for a more thorough examination. Fifth, this research has confirmed that there are no differences between Generations Z, Y and X at the model and path level. In deciding whether they would use ORSs, help others, and perceive ORSs as useful (when they are disappointed with complaint handling), there are no differences between the three generations. This is in line with previous research (Chung, Park, Wang, \& McLaughlin, 2010) that also did not find a moderating role of age on the relationship between perceived ease of use - perceived usefulness, perceived ease of use - behavioural intention and perceived usefulness and behavioural intention to use online communities.

\section{Conclusion}

Because guests have to come out of their comfort zones to express negative thoughts, every complaint made represents an unpleasant situation (conflict) for the guest. Although guest dissatisfaction expressed through complaint is often seen as "par for the course" (with regard to numerous unforeseen situations), every complaint should be taken seriously. To avoid further dissatisfaction and disappointment, in addition to understanding the guest's needs and wants, hospitality workers must be familiar with the procedure and rules of the organization, as boundaries for solving problems. For managers, it is also an important fact that a complaint contains future value for hospitality enterprises, seen through a future relationship with guests. Since dissatisfied guests keep valuable information, managers should ensure a positive climate for sharing their thoughts during their stay. After they get home, an unspoken critic may become an even bigger problem for both sides, which may escalate through negative e-WOM. As this research has confirmed, guests dissatisfied with service recovery are guests who will share a negative voice with others if they get less than what they expected to receive from service recovery. Moreover, guests who are motivated to write negative reviews by their dissatisfaction with complaint handling are more likely to consider ORSs as useful and important when they need to make a new booking decision.

Although recovery represents the reaction to a guest's problem, guest satisfaction need not be an issue if hospitality workers are trained to perceive guests' complaint as feedback or input for better guest understanding. Not only should employees be educated to know the standards in managing guest relationships but they should also be sensitive to signs of guest dissatisfaction and seek to resolve the problem before the guest returns home. According to Faulkner (2003), an organization that effectively seeks to proactively manage complaints reduces the level of escalated complaint significantly. Thus, a proactive way of thinking is even more prominent than the reactive way, since it assumes the prevention of the problem and reduces the need for problem solving. 


\section{Limitations and future research directions}

Several limitations are associated with this research that future research should build upon or avoid. As this is the first study in online complaints research that involves perceived ORS importance and motivation for dissatisfaction with complaint handling, we could not apply the existing scales for the two constructs. Therefore, future studies should work on refining our measures in order to provide better validity. Second, our study does not present differences between all five generations because we did not collect enough participants for the two older generations (Baby boomers and Traditionalists). Future studies should focus more on an equal number of participants to test differences among different

generations. Third, this study does not include other potentially important platforms for UGC (social network sites), such as blogs, microblogs and wikis. Further, our study includes only three antecedents (resulting from exploratory analysis) to altruism. It is important to acknowledge that there might be additional variables that significantly influence altruism. Lastly, we believe that a longitudinal type of research would bring more compelling results (more reliable estimation of generations, change across time and the direction of causal relationships).

\section{References}

Bach, S., \& Kim, S. (2012). Online Consumer Complaint Behaviors: Dynamics of Service Failures, Consumers' Word of Mouth, and Organization-Consumer Relationships. International Journal of Strategic Communication, 6(1), 59-76.

Balaji, M. S., Khong, K. W., \& Chong, A. Y. L. (2016). Determinants of negative word-of-mouth communication using social networking sites. Information and Management, 53(4), 528- 540.

Baym, N. (2010). Personal connections in the digital age. Malden: Polity Press.

Basuroy, S., Chatterjee, S., \& Ravid, S. A. (2003). How critical are critical reviews? The box office effects of film critics, star power, and budgets. Journal of Marketing. 67(4), 103-117.

Benckendorff, P., Xiang, Z., \& Sheldon, P. (2019). Tourism Information Technology. Oxfordshire: CABI. Cheung, C., \& Lee, M. (2012). What drives consumers to spread electronic word of mouth in online consumer-opinion platforms. Decision Support Systems, 53(1), 218-225.

Chevalier, J. A., \& Mayzlin, D. (2006). The effect of word of mouth on sales: Online book reviews. Journal of Marketing Research, 43(3), 345-354.

Chung, J., Park, N., Wang, H. F., \& McLaughlin, M. (2010). Age differences in perceptions of online community participation among non-users: An extension of the Technology Acceptance Model. Computers in Human Behavior, 26(6), 1674-1684.

Crosby, P. (1979). Quality is free. New York: McGraw-Hill.

Faulkner, M. (2003). Customer Management Excellence: Successful strategies from service leaders. Chichester: John Wiley \& Sons Ltd.

Folgado-Fernández, J., Hernández-Mogollón, J., \& Duarte, P. (2017). Destination image and loyalty development: the impact of tourists' food experiences at gastronomic events. Scandinavian Journal of Hospitality and Tourism, 17(1), 92-110.

Fornell, C., \& Larcker, D. F. (1981). Evaluating structural equation models with unobservable variables and measurement error. Journal of Marketing Research, 18(1), 39-50.

Gaskin, J., \& Lyytinen. (2011). Retrieved from www.kolobkreations.com/Mediation\%2oand\%2oMultigroup\%2oModeration.ppt

Gonçalves Santos Silva, R., Liebesny Broilo, S., Balestrin Espartel, L. \& Basso, K. (2017). Altruistic Punishment: A Consumer Response to Service Failure. Journal of Marketing Theory and Practice, 25(4), 421-435.

Gretzel, U., \& Yoo, K. (2008). Use and Impact of Online Travel Review. Vienna: Springer. 
Hair, J., Black, W., Babin, B., \& Anderson, R. (2014). Multivariate Data Analysis. London: Pearson Education Limited.

Hennig-Thurau, T., Walsh, G., \& Walsh, G. (2003). Electronic Word-of-Mouth: Motives for and Consequences of Reading Customer Articulations on the Internet. International Journal of Electronic Commerce, 8(2), 51-74.

Henning-Thurau, T., Gwinner, K., Walsh, G., \& Gremler, D. (2004). Electronic word of mouth via consumer-opinion platforms: what motivates consumers to articulate themselves on internet? Journal of Interactive Marketing, 18(1), 38-52.

Illum, S., Ivanov, S., \& Liang, Y. (2010). Using virtual communities in tourism research. Tourism Management, 31(3), 335-340.

Jiang, J., Zhang, J., Zhang, H., \& Yan, B. (2018). Natural soundscapes and tourist loyalty to nature-based tourism destinations: the mediating effect of tourist satisfaction. Journal of Travel and Tourism Marketing, 35(2), 218-230.

Kim, C., Jin, M., Kim, J., \& Shin, N. (2012). User Perception of the Quality, Value, and Utility of UserGenerated Content. Journal of Electronic Commerce Research, 13(4), 305-319.

Kim, J., \& Grunig, J.E. (2011). Problem Solving and Communicative Action: A Situational Theory of Problem Solving. Journal of Communication, 61(1), 120-149.

Kim, S.J., R.J. Wang, E. Maslowska, and Malthouse, E.C. (2015). Understanding a fury in your words: the effects of posting and viewing electronic negative word-of-mouth on purchase behaviors. Computers in Human Behavior, 54(5), 511-521.

Laškarin Ažić, M. (2018). Upravljanje odnosima s gostima u turizmu i ugostiteljstvu. [Managing guest relations in tourism and hospitality]. Opatija: Fakulet za menadžment u turizmu i ugostiteljstvu.

Li, X., \& Hitt, L. (2008). Self-selection and information role of online product reviews. Information System Research, 19(4), 456-474.

Liu, C., Wu, T., Yeh, P., \& Chen, S. (2015). Equity-based customer loyalty model for the upscale hotelsAlternative models for leisure and business travels. Tourism Management Perspectives, 16(October), 139-147.

Maslowska, E.; Malthouse, E.C., \& Bernritter, S.F. (2016): Too good to be true: the role of online reviews' features in probability to buy, International Journal of Advertising, 36(1), 142-163.

Mattila, A., \& Ro, H. (2008). Discrete Negative Emotions and Customer Dissatisfaction Responses in a Casual Restaurant Setting. Journal of Hospitality and Tourism Research, 32(1), 89-107.

Maxham III, J.G. (2001). Service recovery's influence on consumer satisfaction, positive word-ofmouth, and purchase intentions. Journal of Business Research, 54(1), 11-24.

McCollough, M. and Bharadwaj, S. (1992). The recovery paradox: an examination of consumer satisfaction in relation to disconfirmation, service quality, and attribution based theories. In Allen, C. T. (Ed.), Proceedings of the Winter educators' conference, Marketing theory and applications, (1992), San Antonio: TX,

Meng, F., Dipietro, R.B., Gerdes, J.H., Kline, S., Avant T. (2018). How Hotel Responses to Negative Online Reviews Affect Customers' Perception of Hotel Image and Behavioral Intent: An Exploratory Investigation. Tourism Review International, 22 (1), 23-39.

Mohd Ishar, N.I., \& Mohd Roslin, R. (2016). Dissatisfied response behaviour, negative emotion and dissatisfied service experience: a structural model. Humanities and Social Sciences Review, o6(o1), 213-220.

Munar, A., \& Jacobsen, J. (2014). Motivations for sharing tourism experiences through social media. Tourism Management, 43(August), 46-54.

Munzel, A., \& Kunz, W.H. (2014). Creators, multipliers, and lurkers: who contributes and who benefits at online review sites. Journal of Service Management, 25(1), 49-74. 
Park, D., \& Lee, J. (2008). eWOM overload and its effect on consumer behavioral intention depending on consumer involvement. Electronic Commerce Research and Applications, 7(4), 386-398.

Racherla, P., \& Friske, W. (2012). Perceived 'usefulness' of online consumer reviews: An exploratory investigation across three service categories. Electronic Commerce Research and Applications, $11(6), 548-559$.

Rafaeli, S., \& Noy, A. (2002). Online auctions, messaging, communication and social facilitation: A simulation and experimental evidence. European Journal of Information Systems, 11(3), 196-207.

Richins, M. (1983). Negative Word-of-Mouth by Dissatisfied Consumers: A Pilot Study. Journal of Marketing, 47(1), 68-78.

Robinette, S., \& Brand, C. (2001). Emotion Marketing: The Hallmark Way of Winning Customers for Life. New York: McGraw-Hill.

Sen, S., \& Lerman, D. (2007). Why are you telling me this? An examination into negative consumer reviews on the Web. Journal of Interactive Marketing, 21(4), 76-94.

Shang, R., Chen, Y., \& Shen, Y. (2005). Extrinsic versus intrinsic motivations for consumers to shop online. Information \& Management, 42 (March), 401-413.

Singh, J. (1990). Voice, Exit and Negative Word of Mouth Behaviours: An Investigation Across Three Service Categories. Journal of the Academy of Marketing Science, 18(1), 1-15.

Singh, J., \& Widing, R.E. (1991). What Occurs Once Consumer Complain? A Theoretical Model for Understanting Satisfaction/Dissatisfaction Outcomes of Complaint Responses. European Journal of Marketing, 25(5), 30-46.

Sobel, M. (1982). Asymptotic confidence intervals for indirect effects in structural equation models. Sociological Methodology, 13, 290-312.

Sparks, B., \& Browning, V. (2010). Complaining in Cyberspace: The Motives and Forms of Hotel Guests' Complaints Online. Journal of Hospitality Marketing E Management, 19(7), 797-818.

Steenkamp, J. E. B. M., \& van Trijp, J. C. M. (1991). The use of LISREL in validating marketing constructs. International Journal of Research in Marketing, 8(1), 283-299.

Stevens, J., Spaid, B., Breazeale, M., \& Esmark Jones, C. (2018). Timeliness, transparency, and trust: A framework for managing online customer complaints. Business Horizons, 61(3), 375-384.

Sundaram, D.S., Mitra, K., \& Webster, C. (1998). Word-Of-Mouth Communications: a Motivational Analysis. NA - Advances in Consumer Research, 25(1), 527-531.

Sweeney, J. Soutar, G., Mazzarol, T. (2014). Factors enhancing word-of-mouth influence: Positive and negative service-related messages, European Journal of Marketing, 48 (1/2), 336-359.

Trammell, K. (2006). The blogging of the president. In Williams, A.P. and Tedesco, J.C. (Eds.), The Internet Election: Prospectives on the Web in Campaign 2006, Rowman and Littlefield, Lanham, MD, pp. 133-146.

Ullrich, S., \& Brunner, C.B. (2015). Negative online consumer reviews: effects of different responses. Journal of Product \& Brand Management, 24(1), 66-77.

$\mathrm{W}_{3} \mathrm{C}$. (2015). Retrieved from https://www.w3.org/standards/semanticweb/

WebFX. (2018) Retrieved from https://www.webfx.com/blog/internet/2o-business-review-sites-helpsmall-business/

Xiang, Z., \& Gretzel, U. (2010). Role of Social Media in online travel information search. Tourism Management, 31(2), 179-188.

Yang, F. X., Lau, M.C. (2015). LuXurY" hotel loyalty - a comparison of Chinese Gen X and Y tourists to Macau. International Journal of Contemporary Hospitality Management, 27(7), 1685-1706.

Yi, X., Lin, V.S., Jin, W., \& Luo, Q.L. (2017). The Authenticity of Heritage Sites, Tourists' Quest for Existential Authenticity, and Destination Loyalty. Journal of Travel Research, 56(8), 1032-1048.

Yoo, K., \& Gretzel, U. (2008). What motivates consumers to write online travel reviews? Information Technology ETourism, 10(4), 283-295. 
Received: 09/08/2019

Accepted: 26/o1/2020

Coordinating editor: Stanislav Ivanov 